\title{
Ruh, Soul, Heart, Mind, and Body in the Perspective of Islamic Educational Psychology
}

\author{
Wahyudi Setiawan ${ }^{1}$, M. Tajab ${ }^{2}$, Moh. Toriqul Chaer $^{3}$ \\ Universitas Muhammadiyah Ponorogo, Indonesia ${ }^{1}$ \\ STIT Muhammadiyah Pacitan, Indonesia ${ }^{2}$ \\ STIT Islamiyah Karya Pembangunan Ngawi, Indonesia ${ }^{3}$
}

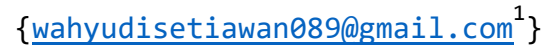

\begin{abstract}
The embodiment of himself as the perfect man is part of the ultimate purpose of life. God as The Almighty gave life to human beings at once the guidelines so that people can become perfect beings. Islam became a conducting ordinary human life in the world hereafter to rediscover the nature itself. In the attainment ofthe perfection of the social life, then he must learn to understand and execute rights and obligations between spirit, soul, heart, intellect, and as a unit of the component in the form of a human being. Through the study of Eastern and Western scientific literature by using content analysis to understand existing data, this study is expected to generate comprehensive information. Spirit is not the immortal beings but is a creation of God is timeless. The soul is the container of the motion was born, and the inner man and the heart is the essential nature of the human being in life. The sense of social considerations become a tool to distinguish between good and evil. The Agency is a container of human inner form was born. Human perfection can only be achieved through education, the dissemination of human nature, his creation, and his goal. In the end, the humans would be able to return to God with the survivor.
\end{abstract}

Keywords: Humans, Psychology, Islamic Education

\section{Introduction}

Discuss human means are talking about the complexity that exists within man himself. Dr. Alexis Carrel says that man is the mysterious creature, because of the degree of detachment from the man himself is inversely proportional to his concern that high against the world that exists outside of himself. Called so because of the degree of detachment from the man himself is inversely proportional to his attention is so high to the world that exists around it (Nata, 2005). This opinion at once shows how difficult it is to understand humans entirely and thoroughly. So every time someone finished understanding of one aspect of a human being, then the other elements also arise.

Socrates refers humans as social animals (Zoon Politicum), Max Scheller assume humans are animals that are sick (Das Kranke Pier), at Drijakara with the mention of the man who is always nervous and troubled (Tafsir, 2010). Furthermore, Aristotle defines man as sentient animals who are capable of speech and speak his mind is based (the animal than reasons), in addition to animal politics (the political Zoo) and social (social animal). Harold h. Titus put 
man as an animal organism capable of studying myself as well as being able to interpret life forms at the same time being able to delve into the meaning of human existence (Saifuddin, 1987).

Human beings (Asy'ari, 1999) (Departemen Pendidikan Nasional. Kamus Besar Bahasa Indonesia, n.d.) are God Almighty and also social beings. In the Islamic view, as creatures of Allah SWT humans have certain tasks in running his life in this world. Tafsir (2008) explains that humans are creatures of God's creation; He does not appear by itself or by itself. Qur'an Sura al-Alaq verse 2 tells us that God created man from a plume of blood; Al Qur'an al-Thariq verse 5 tells us that man was made by God, the Qur'an surat ar-Rahman paragraph 3 explains that ar-Rahman (God) that is what created the humans. Thus, man is a creature of God (Mujib Abdul \& Yusuf, 2006).

The Qur'an speaks about the creation of man with the word khalaqa which means creating or Shaper (Manzur, 1968). The word "khalaqa" refers to the notion of creating something new, without any prior example or it can also apply to understand something of the provisions or the right size (Jamin \& et all, 1998). The Qur'an has many vocabularies about humans, each word is not merely a synonym but also contain symbolic meanings of which in the Qur'an is called human beings, among others, with the bastard (Cave al-Q.s. (18): 110), al-insan (Q.s. (al-Insan (76): 1), an-Nas (Q.s. an-Nas (114): 1). The Qur'an mentions the term employee of as much as 65 times, ins 12 times, five times, unas anasiyya one time, annas 250 times, bastard 37 times, the sons of Adam Adam Hurriyat seven times and two times (Mubarok, 2001).

The creation of man consists of a physical form that is concrete, also accompanied the grant portion of the spirit of God Almighty that is abstract(Muhaimin \& Abdul Mujib, 1993). The same symptoms were found in thinking Islamic education which persists in the classic debate about human existence in the process of education. It can be presumed that became the reference normative are three mainstream education stream that in fact was developed by Western figures. The reference in question is a stream of nativism, empiricism, and convergence was developed by John Locke (1632-1704), William Stern (1871-1928), and Schoupenheuer (1788-1860). Humans are characterized by a central intelligence or total or partial rather than just the edges. Humans are characterized by the ability to love and sincerity, not merely reflected egotistical. Whereas, animals, not knowing anything about it outside of the sensorial world, although perhaps having a sensitivity about the sacred (Norma, 1997).

Humans need to recognize the substance itself, so that it makes sense that he used to master nature and the universe are all controlled by faith, so that it is able to recognize God's omniscience to mighty in creating and controlling the lives of his creation. In understanding the verses of God in the sense of human nature itself, be able to give her life meaning and significance, to be filled in with a submissive and obedient to the commandments and trying to avoid the prohibitions of God.

Man uses his instincts were to know all things in his life. Starting his knowledge in terms of looks and empirical to the unseen outside of his ability. Understand the spirit, soul, heart, and everyone has varying opinions, respectively, would not have the same perception we encounter in understanding it. This is because each person's length of aft the background and a different perspective to infer any problems. Spirit to the present position in the debate between people with one another. Some opinions for example as be delivered by Ibn Qayyim with an excerpt of some writers that the spirit will experience death. Because the spirit is likened to the soul, and every soul must have felt death, and remains Perhaps Face who has greatness and glory (Q.S. Ar-Rahman, 27), each something surely perishes unless the face of God (Q.S. AlQashash, 88). 
The others contend that the spirit does not suffer death, he continues to live his life as a man. He argued that if the spirit of the dead then he would never be able to feel the pleasure and torment of his actions during the life of the world. Do not think that people who fall in the way of God are dead; even those that live beside their Lord with sustenance. They are in a State of excited due to the grace of God given unto them, and they rejoice against the people who are left behind who have not followed them, that there is no concern over them and not (also) nor shall they grieve (Q.S. Ali-Imran, 169-170).

The term ruh in different everyday vocabulary with the term spirit. Ruh meaning spirit or spirit while the spirit is often compared to the mean with the soul that makes a person life or could live (Rahardjo, 2002). Although the word spirit and this spirit is already plural used in common languages, such as the development of spiritually educational, spiritually for example but the sense turns out to contain a few different meanings. In the spirit of United Kingdom language translated as "spirit" while the life or soul translated "soul". While in Al-Qur'ān, the spirit that the translation of the word "Al-Ruh", while the soul or the life of the translation of the word "Al-Nafs". In Islamic Psychology seminar in Yogyakarta 1994 (Rahardjo, 2002), said that became a reference and is the basic concept of Al-Qur'ān with regard to man is the Spirit and the Nafs. The Word Spirit comes from the $\mathrm{r}-\mathrm{w}-\mathrm{h}$. These words arise from the word rāha, rīh, rayhān, rūh, arāha. Rāha means departure, rīh (wind), rayhān (pleasure), rūh (spirit). From the above sense then the spirit in the conception of language Al-Qur'ān are smooth and lightweight, so blown that plus spirit man and not perish because of the physical body perished. He then perfected and breathed into him the spirit (creation) of her and she makes your hearing, vision, and heart; (but) you little thankful (Q.S. As-Sajdah, 9).

Al-Spirit (Dalhat, 2015) that exists in the physical body is of two kinds, the first so-called death while (al-d. al-Sugra), occurs during sleep, and then the actual death (al-d. al-Kubra). In both occasions, the spirit leaves the body, though its nature is not the same degree of departure. For example, when asleep, Spirit did not fully separate his physical body, but rather to wander, as she breathed so much so that when she wakes up, she will be back again. It is based on the verse of Al-Qur'ān that is, God holds the soul of (people) when the death and (holding) of the soul (people) who have not been dead at the time of his sleep; then he holds the soul (people) which he had set his death and she let go of the other until the set time. Surely in this, there are signs of Allah for a people who think (Q.S. Az-Zumar, 42).

\section{Result and discussion}

\subsection{The Nature of the Spirit and its Relationship With the Body}

The Qur'an uses the two terms are often used to capture the notion of the soul, namely the ruh (spirit) and the nafs. Because the essence of the spirit and the soul of that unseen than to capture the understanding required some other term such as qalb, 'aql, fuad, albab. The fourth term is actually still is non-physical. Physical components to qalb and fu'aad is liver, to aql and albab is the brain. Understanding of the existence and function of the spirit or the soul discerned by considering how some elements already mentioned it's running its functions in everyday life of human beings (Afrizal, 2014).The Quran does not explain the fact that spirit. The ignorance of man against nature spirit indeed better than busy steeped in reality, because the spirit and the soul is the secret of God. Soluble in talk about it might be spending time alone while the results will be worth it. Thus, take only a little knowledge of it as teaching in life. 
The term ruh quoted as much as 21 times scattered in the Koran and refer to different contexts. Whom God tells Prophet Isa as creation events without the father and the Holy Spirit strengthen it with blown to his mother Mary. This is a miracle for Prophet Isa with different events human beings in General, and to rebut the opinion of Jews who accused the Mary, the mother of the Prophet Jesus who was accused of doing wrong. Al-Baqarah verse 87 and 253 Nisak 171, al-, al-Maidah 110. On the other hand, the spirit means the Angel Gabriel brought revelation as a warning to mankind, surat al-Nahl: 2, 102, al-Syu'ara: al-Mukmin, 193, 15, alMa'arij: 4, al-Naba: 38, al-Qadr: 4, Maryam: 17. There is a spirit that is defined as with the peace because with faith be calm, al-Mujadalah, 22. There is a spirit that is defined by the Quran, Quran because it revives the faith of people who got as instruction, al-Shura: 52. In the letter al-Abijah ' 91, al-Tahrim: 12, al-Sajda: 9, al-Hijr: 29, Shad: 72, describes the process of God's creation of man perfectly with blown spirit from God, to demonstrate the power of God (Afrizal, 2014). In addition to the term ruh al-Quran also mentions the term nafs in various forms as much as 298 times scattered in different letters. The term nafs more now. Is the body here not rough body such as the head, body, and members, but that question has already breached the spirit of the body. If the body of the dead initially passive, not moving, then after he breached the spirit come alive and active. If the called man then surely that question is the body with his spirit and who have been fused.

Ruh is the substance of the human psychic who became the essence of his life. Some experts call the spirit as the delicate body (jism Latif), there is a simple substance (jauhar basith), and there is also substance spiritually (jauhar spiritually). The spirit becomes a differentiator between the essence of the essence of human beings. Different spirit with the spirit in the terminology of psychology, because the term ruh meaning jauhar (substance use), while the spirit more aradh (accident) (Yudiani, 2016). Spirit as a substance that has its own nature. According to Ibn Sina, ruh is the perfection of the beginning of mass high natural human life with power. As for al-Farabi, the spirit comes from natural commands (amar) that have a different nature with the remains. It is because it comes directly from God, although he is not the same as its substance. Currently, according to al-Ghazali, this spirit is lathifah (something) that is spiritually. He can think, remember, and so on. He also served as the driving force for the existence of human remains. Supernatural nature. While the Averroes looked ruh as the image of perfection for natural organic remains. Perfection as perfection early because of the spirit can be distinguished by the excellence of the other which is a compliment to himself, as found in the various works. While called organic because the spirit shows remain of which consist of organs.

The question that arises is, what's the difference Al-Nafs and Ruh and Al-Hayat? Whether it is a form or abstract? Opinions about this as confirmed by scholars such as al-Qurtubi (1967), Ibn Taymiyah (1988) and disciple of Ibn Qayyim (2004) is that the difference between the two is that attributes rather than substance (Dalhat, 2015). Who are more tyrants than the people who make the falsehood against Allah or that said: ' it has been revealed to me', but there is no revealed nothing to him, and the man said: 'I'll lose like what God sent down. 'It would be awesome is if you look at the people that tyrants are in pressure in death, the angels are hitting with hands, (saying): 'Removable' which in this day you shall be with the torment of a very humiliating, because you always say against God (Word) that is not true and (because) you always brag against his (Q.S. Al-An'am, 93). This verse tells us that the Spirit is a clear substance and different with Al-Nafs, so ordered to be issued in in death. Because of that spirit does not vanish with a his hurt body. Spirit also has advantages proclivity to the truth as well as long for his God. They ask thee concerning the spirit. Say: 'the spirit that 
includes God's Affairs, nor would you be given the knowledge but rather a bit' (Q.S. Al-Isra', $85)$.

\subsection{The Existence of the Spirit, the Soul, the Heart, the Intellect, and the Body in Islamic Education Psychology Perspective}

Attainment of the perfection of human beings as creatures of the world while the afterlife could not be realized to the maximum without any process of a good education. Humanizing education human beings really know would be his position as a servant and leader for himself at once in the world. Ibn Khaldun perceives that humans became part of the history is civilization that has the most important role. The existence of civilization in human history are engraved and recorded perfectly because people continue to do the exploration of emotional intelligence, while the spiritual within him (Hafidz Hasyim, 2010). Makes sense that has exceptional intelligence as God's gift turns out to be able to make an increasingly strong and survive in any condition. Positive thoughts and positive emotional perspective into the main human capital are becoming increasingly perfect (Rahmasari, 2016). The various human effort is made to identify herself and her God, who are educational in boarding school. Education at pesantren tried delivering every human being to understand, understand, and know him as the perfect creature (Madjid, 1985). Started since early humans had to be educated to achieve perfection.

The soul is closely related to the body that acts as a container of human abstraction thing. The existence of the soul in man declare is a form of human existence itself (Anthony Quinthon, 1962). The soul becomes the driving force of human beings with all the dimensions. Because the soul is a sacred thing that resides within (Hanson, n.d.). Humans as individuals who have the freedom to manifest themselves (self-realization), either as a self (individual) or as social beings, it cannot escape from its various attachment to neighboring districts. Attachment or the limitations of human nature that is inherent and taken since man invented God Almighty. The limitations of responsibility demand heavier than other creatures.

There must be maximum efforts so that people remain in a good position, educators and learners must together mutually understand that learning priorities are to get to know yourself and your knowledge (Ball, 2003). The soul must be always be educated in goodness because each deed always involves people (Palmer, 2003). The process of a good education is a key to how the soul will be born in good. Do not close the possibility if errors in running the educational process then the souls will experience disability or even got worse (Warner, 2009). Implementation of modern education is currently starting to realize that technology and materialism have affected the happiness of the human soul. Maximum effort is the most important part in realizing the goals of human education as human beings.

\section{Conclusion}

Spirit is not the immortal beings, but is a creation of God is immortal. The soul is the container of the motion was born and the inner man, and the heart is the essential nature of the human being in life. The sense of human considerations become a tool to distinguish between good and evil. The Agency is a container of human inner form was born. Human perfection can only be achieved through education, the dissemination of human nature, his creation, and his goal. In the end, the humans would be able to return to God. The conception of psychology education in Islam this is important as the entrance to developing spiritual intelligence of humans who are aware of the meaning of life in a frame of revelation. With this spirit, besides 
leading to mental health, it is also a good personality. Because the spirit of God, which tend to be carrying mankind always remember and run the religion properly. While mental health according to Abdul Mujib namely health spiritual that where individuals feel calm and serene setting in run command of God Almighty, obtaining the happiness of the world and the hereafter. Another implication of the perspective of the spirit according to Mujib is the paradigm of psychology. Psychology is not only concerned with the empirical problems-but also empiricalmeta inductive-deductive based on divine revelation. On the other hand, it AlQur'ān also confirmed that we were given a bit of a science of the spirit, and that is God's affair.

\section{References}

Afrizal, M. (2014). Pemikiran Para Filosof Muslim Tentang Jiwa. ANIDA, 39(1), 1-17.

Anthony Quinthon. (1962). “The Soul.” The Journal of Philosophy, 59(15), 393-409.

Asy'ari, M. (1999). Peradaban Islam Modern. Jakarta: PT. Grafindo Persada.

Ball, S. J. (2003). The Teacher's Soul and the Terrors of Performativity. Journal of Education Policy, 18(2), 215-28.

Dalhat, Y. (2015). The Concept Of Al-Ruh (Soul) In Islam. International Journal of Education and Research, 3(8), 431-40.

Departemen Pendidikan Nasional. Kamus Besar Bahasa Indonesia. (n.d.). Jakarta: Balai Pustaka.

Hafidz Hasyim. (2010). "Watak Peradaban Dalam Epistemologi Ibnu Khaldun.” Humaniora, $3(22), 336-47$.

Hanson, S. E. (n.d.). Connections Between Body and Soul: The Asceticism of Medieval Saints.

Jamin, A. R., \& et all. (1998). Jakarta: PT. Raja Grafindo Persada. Jakarta: PT. Raja Grafindo Persada.

Madjid, N. (1985). "Merumuskan Kembali Tujuan Pendidikan Pesantren.” Dalam Dawam Rahardjo,. In P3M (Ed.), Pergulatan Dunia Pesantren: Membangun Dari Bawah. Jakarta.

Manzur, I. (1968). Dar al-Misriyah li at-Ta'lif wa at-Tarjamah.jilid (Vol. 1). Mesir: Lisan al'Arab.

Mubarok, A. (2001). Psikologi Qur'ani. Jakarta: Pustaka Firdaus.

Muhaimin, \& Abdul Mujib. (1993). Pemikiran Pendidikan Islam Kajian Filosofis dan Kerangka Dasar Operasionalnya. Bandung: PT Trigenda Karya.

Mujib Abdul, \& Yusuf. (2006). Pengantar Pendidikan Islam. Jakarta: Rencana Prenada Media Group.

Nata, A. (2005). Filsafat Pendidikan Islam. Jakarta: Gaya Media Pratama.

Norma, A. (1997). Hakikat Manusia. (Norma Ahmad, Ed.). Yogyakarta: Hakikat Manusia.

Palmer, J. P. (2003). Reflections on Spirituality in Teacher Education. Journal of Teacher Education, 54(5), 376-385.

Rahardjo, M. D. (2002). Ensiklopedi Al-Qur'ān: Tafsir Sosial Berdasarkan Konsep Konsep Kunci (2nd ed.). Jakarta: Paramadina.

Rahmasari, L. (2016). Pengaruh Kecerdasan Intelektual, Kecerdasan Emosi Dan Kecerdasan Spiritual Terhadap Kinerja Karyawan. Majalah Ilmiah Informatika, 3(1).

Saifuddin, A. E. (1987). Ilmu Filsafat dan Agama. Surabaya: Bina Ilmu.

Tafsir, A. (2010). Filsafat Pendidikan Islam. In Integrasi Jasmani, Rohani dan Kalbu Memanusiakan Manusia. Bandung: Remaja Rosdakarya.

Warner, S. A. (2009). The Soul of Technology Education: Being Human in an Overly 
Rational World.

Yudiani, E. (2016). Dinamika Jiwa Dalam Perspektif Psikologi Islam. Jurnal Ilmu Agama, 14(1), 45-60. 